\title{
Differential activity of nitric oxide synthase in human nasal mucosa and polyps
}

\author{
I. Ramis*, J. Lorente**, J. Roselló-Catafau*, P. Quesada**, E. Gelpí*, O. Bulbena*
}

Differential activity of nitric oxide synthase in human nasal mucosa and polyps. I. Ramis, J. Lorente, J. Roselló-Catafau, P. Quesada, E. Gelpí, O. Bulbena. CERS Journals Ltd 1996.

ABSTRACT: Nitric oxide (NO) plays an important regulatory role in airway function and seems to be implicated in the pathophysiology of several airway diseases. To better understand the involvement of NO in the upper airways, we examined the presence of nitric oxide synthase (NOS) activity in human nasal mucosa and nasal polyp tissues.

Nasal mucosa was obtained from seven patients undergoing septoplasty, and nasal polyps came from nine patients following polypectomy. NOS activity was quantified in tissue homogenates using the citrulline release assay and localized in tissue sections using reduced nicotinamide adenine dinucleotide phosphate (NADPH)diaphorase histochemistry.

The results showed that nasal polyps $(n=9)$ contained higher levels of total NOS activity (mean $\pm \mathrm{SD} 5.94 \pm 5.71$, range $1.29-18.0 \mathrm{pmol} \cdot \mathrm{min}^{-1} \cdot \mathrm{mg}$ protein) than nasal mucosa tissues $(\mathrm{n}=7)\left(0.28 \pm 0.22\right.$, range $0.01-0.57 \mathrm{pmol} \cdot \mathrm{min}^{-1} \cdot \mathrm{mg}^{-}$protein). In addition, nasal polyps mainly contained inducible NOS activity $(4.67 \pm 4.57$, range 1.23 $15.5 \mathrm{pmol} \cdot \mathrm{min}^{-1} \cdot \mathrm{mg}$ protein) whereas in nasal mucosa all NOS activity detected was in constitutive form. In both cases, NOS activity was localized in the epithelial cells.

Since NO synthase is induced in inflamed upper airways, we conclude that NO may be an important inflammatory mediator in the respiratory system and that the epithelium may be a source of NO production in the human upper airways. Eur Respir J., 1996, 9, 202-206.
*Dept of Medical Bioanalysis, Centro de Investigación y Desarrollo, CSIC, Barcelona, Spain. **Dept of Otorhinolaryngology, Hospital General Universitario Valle de Hebrón, Barcelona, Spain.

Correspondence: I. Ramis Dept of Medical Bioanalysis Centro de Investigación y Desarrollo CSIC

Jordi Girona 18-26

08034-Barcelona

Spain

Keywords: Nasal mucosa nasal polyposis

NADPH-diaphorase

nitric oxide synthase

Received: April 191995

Accepted after revision October 311995

Supported by grants No. 92/0281 and 93/0913E from the Fondo Investigación Sanitaria of Spain.
Nitric oxide (NO) has been identified as an important mediator in numerous physiological and inflammatory processes $[1,2]$. NO formation was first described in endothelial cells [3], and was subsequently reported in many cell types, such as neurons, fibroblasts, platelets, macrophages, neutrophils and epithelial cells [4,5]. NO is formed from L-arginine via the action of the enzyme NO synthase (NOS). NOS exists in constitutive (i.e. continuously present in the cells) and inducible forms (expressed following activation by cytokines and bacterial endotoxin). There are two different constitutive forms (cNOS), one typically found in neural cells [6] and another typically found in vascular endothelial cells [7], both of which are $\mathrm{Ca}^{2+} /$ calmodulin-dependent. There is only one inducible form (iNOS), which is $\mathrm{Ca}^{2+}$ independent, found in activated cells, such as macrophages and hepatocytes [8].

Recent observations suggest that L-arginine-dependent NOS is present in different pulmonary cell types, and that it may play a role in various regulatory mechanisms in the airways and lung tissue [9]. The fact that inhaled NO is capable of producing selective pulmonary vasodilation in animals and humans [10] has provided a rational basis for its use in intensive care as an effective therapeutic agent in pulmonary hypertension [11], and the adult respiratory distress syndrome (ARDS) [12]. In addition to its vasorelaxant properties, there is evidence in vivo which suggests that NO plays a role in the modulation of bronchomotor tone in guinea-pigs [13], and humans [14]. Overall, these data suggest that NO may have relevant functions in the regulation of vascular and bronchial smooth muscle.

Added to its therapeutic potential, there is experimental evidence suggesting that NO may be an endogenous mediator in the pulmonary system. In this sense, NOS activity has been found in lung tissue preparations [15]. This activity has also been localized in several pulmonary cell types by histochemistry and immunohistochemistry [16], and NO has been found in parts per billion (ppb) levels in the air exhaled by experimental animals and humans [17]. Along these lines, an increased amount of NO in air exhaled by asthmatics has been reported [18]. This same report showed that the major proportion of the NO in the air exhaled by control subjects seemed to originate in the nasal airways; however, in mild asthmatics there was a major contribution from the lower 
airways [18]. The same authors have recently reported that the major source of NO from the upper airways is the maxillary sinus [19]. Nevertheless, a biochemical and histochemical analysis of NO production by the human upper airways, both in healthy and pathological conditions, has not been performed. Since nasal polyps constitute a chronic inflammatory process and NO plays an important role, both in acute and chronic inflammation $[20,21]$, we have examined the NOS activity levels in nasal polyps relative to those in healthy nasal mucosa. The purpose of this study was to ascertain whether NOS activity is present in the human upper airways, the proportion of isoforms, its precise location, and to determine the differences between inflamed and noninflamed tissues.

\section{Material and methods}

\section{Tissues and reagents}

Nasal polyps were obtained from nine patients (6 females and 3 males, aged 35-68 yrs) undergoing polypectomy; all patients were receiving topical corticosteroids and four of them received oral corticosteroid treatment as well. Nasal mucosa tissues were obtained from seven patients ( 3 females and 4 males, aged 32-61 yrs) operated for functional septoplasty; subjects did not receive any medication prior to surgery. The specimens (nasal mucosa and nasal polyps) were collected at the time of surgery in Hank's balanced salt solution (HBSS) without calcium and magnesium (Gibco, Grand Island, NY, USA) containing $20 \mathrm{mM}$ hydroxyethylpiperazine ethanesulphonic acid (HEPES), and were immediately processed. For NOS activity studies, tissues were frozen and stored at $-70^{\circ} \mathrm{C}$. For NADPH diaphorase histochemical staining, tissues were cut into several pieces at a thickness of about $5 \mathrm{~mm}$ and fixed in periodate-lysineparaformaldehyde at $4^{\circ} \mathrm{C}$ for $3 \mathrm{~h}$, and successively transferred to $0.1 \mathrm{M}$ phosphate buffer, $\mathrm{pH} 7.4,10 \%$ sucrose, $20 \%$ sucrose and $30 \%$ sucrose at $4^{\circ} \mathrm{C}$ for $3 \mathrm{~h}$. The tissues were then frozen in Tissue-Tec ornithine carbamyl transferase (OCT) (Miles, Elkhart, IN, USA) in liquid nitrogen and stored at $-70^{\circ} \mathrm{C}$. Eight micron thick sections were obtained in a cryomicrotome, thaw-mounted on microscope slides coated with 2\% 3-aminopropyltriethoxysilane (Sigma, St Louis, MO, USA). Slides were air-dried and stored at $-40^{\circ} \mathrm{C}$ until assessment.

\section{Assay of NOS activity}

NOS activity was measured in nasal polyp and nasal mucosa homogenates, after partial purification by 2 '.5'adenosine diphosphate (ADP)-Sepharose chromatography by ${ }^{3} \mathrm{H}$-citrulline production from ${ }^{3} \mathrm{H}$-arginine as described previously [22]. Briefly, tissues were homogenized in $20 \mathrm{mM}$ Tris buffer $\mathrm{pH} 7.5$, containing $0.5 \mathrm{mM}$ ethylene glycol tetra-acetic acid (EGTA), $0.5 \mathrm{mM}$ ethylenediamine tetra-acetic acid (EDTA), $1 \mathrm{mM}$ dithiothreitol, $0.2 \mathrm{mM}$ phenylmethanesulphonyl fluoride, $1 \mathrm{mM}$ tetrahydrobiopterin and $1 \mu \mathrm{M}$ leupeptin. Citrulline release was measured at $\mathrm{pH} 7.4$ in a buffer containing $20 \mathrm{mM}$ HEPES, $10 \mu \mathrm{M}{ }^{3} \mathrm{H}$-arginine $(0.3 \mu \mathrm{Ci})$ and $0.5 \mathrm{mM}$ NADPH $(200$ $\mu \mathrm{L}$ of incubation volume). After $10 \mathrm{~min}$ of incubation at $37^{\circ} \mathrm{C}$, the reaction was stopped by adding $800 \mu \mathrm{L}$ of water at $80^{\circ} \mathrm{C}$. This mixture was applied to a $1 \mathrm{~mL}$ Dowex AG50WW-X8 column ( $\mathrm{Na}^{+}$-form) and ${ }^{3} \mathrm{H}$-citrulline was eluted in $3 \mathrm{~mL}$ of water. The radioactivity was measured by liquid scintillation counting. The activity was assayed either in the presence of $100 \mu \mathrm{M} \mathrm{Ca}^{2+}$ or $1 \mathrm{mM}$ EGTA. The rate of production in the presence of 100 $\mu \mathrm{M} \mathrm{Ca}^{2+}$ corresponded to total NOS, and the rate of production in absence of $\mathrm{Ca}^{2+}$ and in presence of $1 \mathrm{mM}$ EGTA corresponded to inducible NOS. The measured activity, nonspecifically inhibited by $1 \mathrm{mM} \mathrm{N}{ }^{\omega}$-nitro-Larginine (L-NNA), was subtracted in both reactions (with $\mathrm{Ca}^{2+}$ or with EGTA). Constitutive NOS was calculated from the difference between total and inducible NOS.

\section{NADPH diaphorase staining}

Sections were rinsed with phosphate-buffered saline (PBS) to remove the OCT compound. The slides were then incubated at room temperature with a mixture consisting of $0.25 \mathrm{mg} \cdot \mathrm{mL}^{-1}$ nitroblue tetrazolium, $1 \mathrm{mg} \cdot \mathrm{mL}^{-1}$ $\beta$-NADPH and $0.5 \%$ Triton X-100 in $0.1 \mathrm{M}$ Tris buffer, $\mathrm{pH} 7.6$ for $1 \mathrm{~h}$, as described previously [16]. Sections were then washed in PBS and covered with Aquatex mounting medium (Merck, Darmstadt, Germany). For control purposes, either the $\beta$-NADPH was omitted or the $15 \mathrm{mM} \rho$-nitrophenylphosphate was added, to inhibit endogenous phosphatases that can cause false-positive staining [23].

\section{Statistical analysis}

Within nasal polyp tissues, Wilcoxon matched-pairs signed-ranks test (two-tailed) was used to compare constitutive versus inducible NOS activity. The MannWhitney U-test was used to assess differences between constitutive NOS from nasal polyp and nasal mucosa tissues (Statistical Package for the Social Sciences (SPSS)/ $\mathrm{PC}^{+}$program; SPSS Inc., Chicago, Illinois, USA).

\section{Results}

Data from the citrulline release assay showed that NOS activity was present in normal human nasal mucosa and in nasal polyps. Total NOS activity ranged 1.29$18.0 \mathrm{pmol} \cdot \mathrm{min}^{-1} \cdot \mathrm{mg}$ protein in nasal polyp tissues (mean $\pm \mathrm{SD}$ $5.94 \pm 5.71 \mathrm{pmol} \cdot \mathrm{min}^{-1} \cdot \mathrm{mg}$ protein; $\left.\mathrm{n}=9\right)$ and $0.01-0.57$ $\mathrm{pmol} \cdot \mathrm{min}^{-1} \cdot \mathrm{mg}$ protein in nasal mucosa tissues $(0.28 \pm$ $0.22 \mathrm{pmol} \cdot \mathrm{min}^{-1} \cdot \mathrm{mg}$ protein; $\left.\mathrm{n}=7\right)$. Whereas both $\mathrm{Ca}^{2+}$ dependent (constitutive) and $\mathrm{Ca}^{2+}$-independent (inducible) NOS activities were detected in nasal polyp tissues (fig. 1a), only $\mathrm{Ca}^{2+}$-dependent NOS activity was detected in healthy nasal mucosa tissues (fig. 1b). Constitutive NOS 
a)

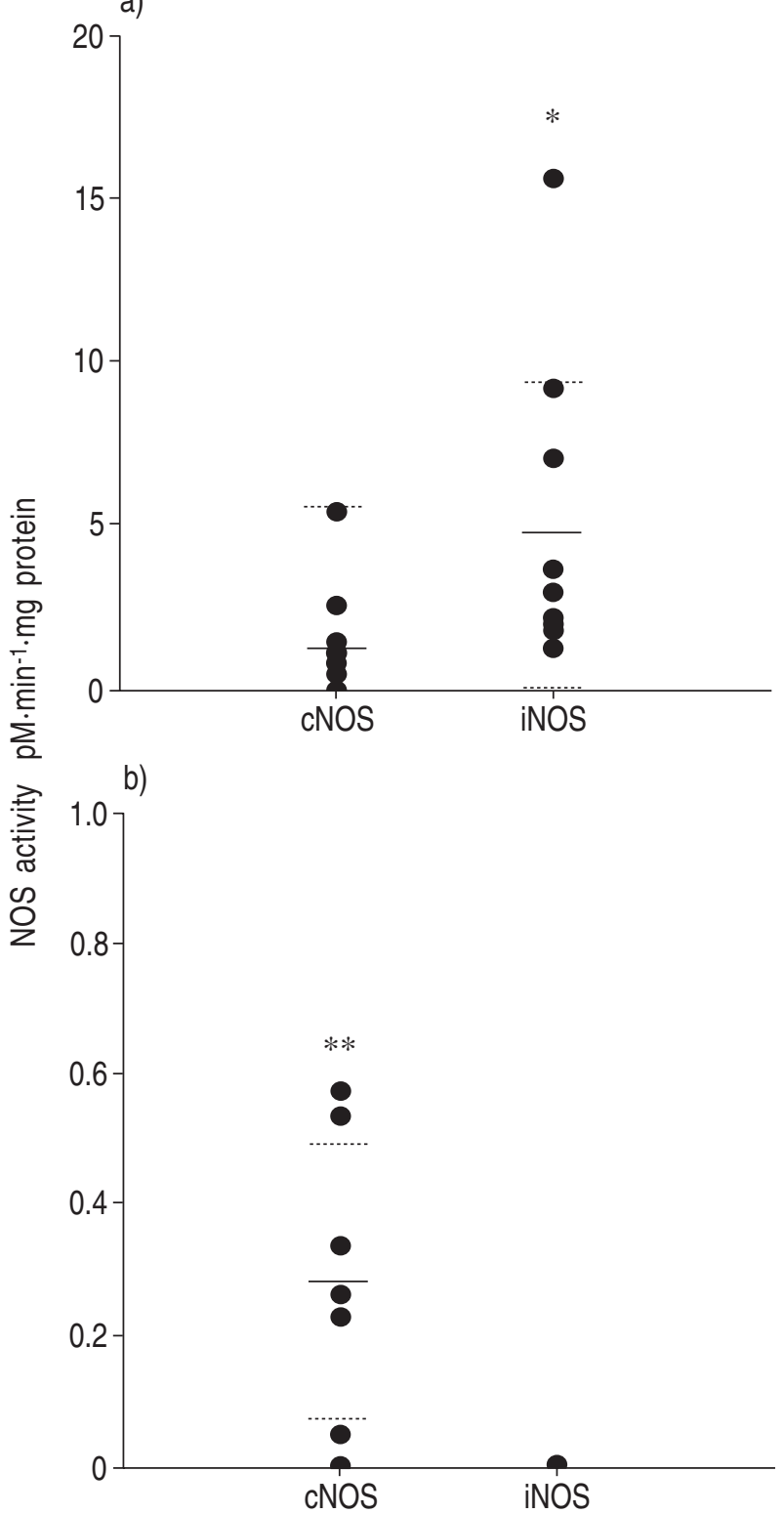

Fig. 1. - Constitutive (cNOS) and inducible (iNOS) nitric oxide synthase (NOS) activity in: a) nasal polyp $(n=9)$; and b) nasal mucosa $(\mathrm{n}=7)$ tissues measured as L-citrulline production $\left(\mathrm{pmol} \cdot \mathrm{min}^{-1} \cdot \mathrm{mg}\right.$ protein). Solid lines represent the mean and dashed lines represent the standard deviation. *: $\mathrm{p}<0.05$ when comparing iNOS $v s$ cNOS activity in nasal polyp tissues using the Wilcoxon test. **: $\mathrm{p}<0.05$ when comparing cNOS from nasal mucosa $v s$ nasal polyp using the MannWhitney U-test. Note much lower levels in nasal mucosa.

activities in nasal mucosa and nasal polyp tissues ranged $0.01-0.57 \mathrm{pmol} \cdot \mathrm{min}^{-1} \cdot \mathrm{mg}$ protein and $0.07-5.34$ $\mathrm{pmol} \cdot \mathrm{min}^{-1} \cdot \mathrm{mg}$ protein, respectively, and were statistically higher in nasal polyps $\left(1.27 \pm 1.60 \mathrm{pmol} \cdot \mathrm{min}^{-1} \cdot \mathrm{mg}\right.$ protein $)$ than in nasal mucosa tissues $\left(0.28 \pm 0.22 \mathrm{pmol} \cdot \mathrm{min}^{-1} \cdot \mathrm{mg}\right.$ protein; $\mathrm{p}<0.05$, Mann-Whitney U-test).

In nasal mucosa $100 \%$ of total NOS activity was constitutive, whereas in nasal polyp $80 \%$ of the total NOS activity present was inducible. Inducible NOS activity in nasal polyps ranged $1.23-15.5 \mathrm{pmol} \cdot \mathrm{min}^{-1} \cdot \mathrm{mg}$ protein, and this inducible form was statistically higher (4.67士 $4.57 \mathrm{pmol} \cdot \mathrm{min}^{-1} \cdot \mathrm{mg}$ protein) than the constitutive form
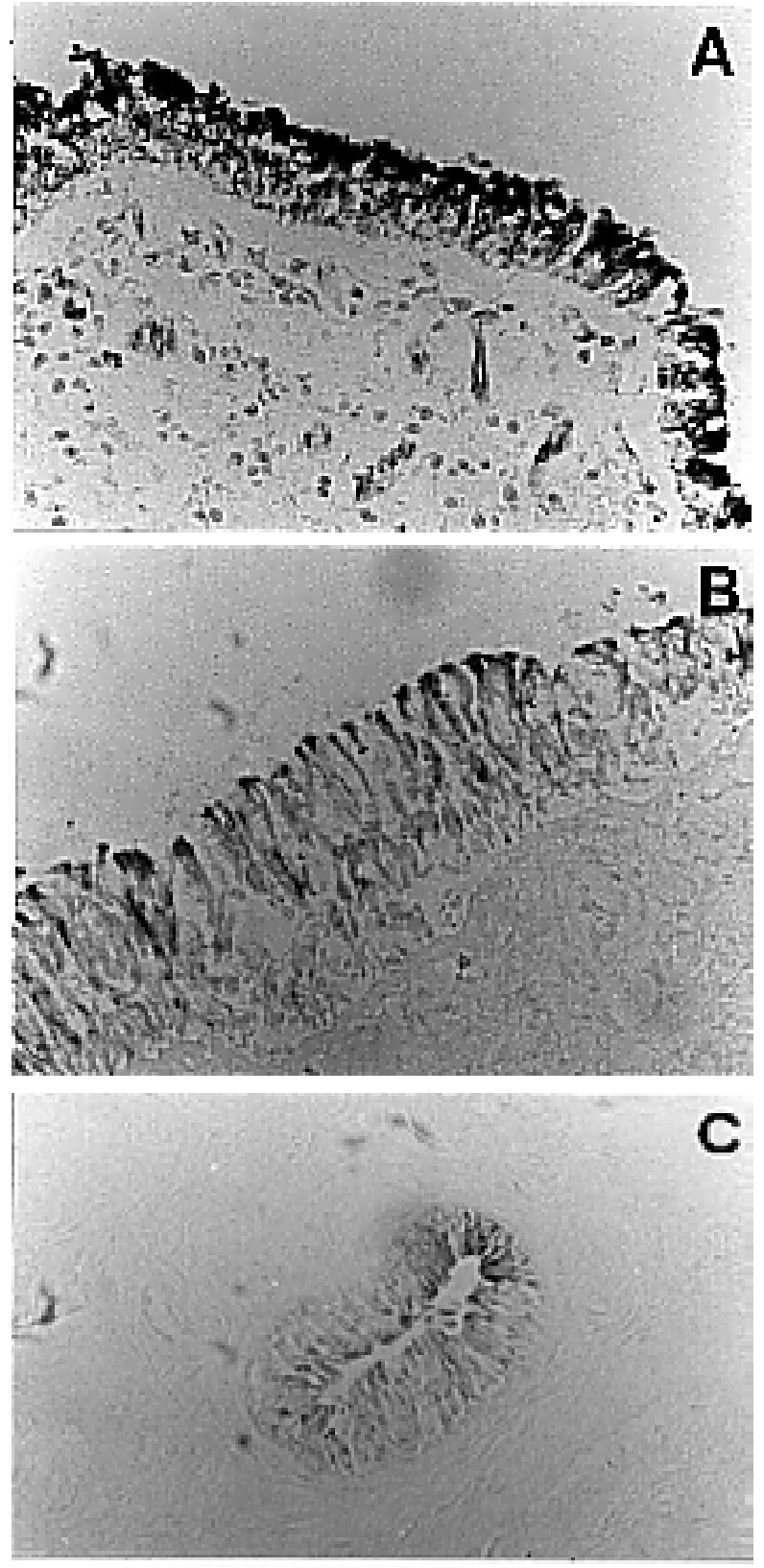

\section{$100 \mu \mathrm{m}$}

Fig. 2. - NADPH-diaphorase histochemical staining in: A) nasal polyp tissue: and $\mathrm{B}$ and $\mathrm{C}$ ) nasal mucosa. Positive cells are identified by their dark-black staining. All epithelium is strongly stained in nasal polyps (A). In contrast, nasal mucosa epithelium either from airway (B) or the glandular epithelium (C) are not intensely stained. NADPH: nicotinamide-adenine-dinucleotide phosphate (reduced form). (Magnification $\times 20$; scale bar $=100 \mu \mathrm{M}$ ).

from the same polyp tissues $(\mathrm{p}<0.05$, Wilcoxon matchedpairs test).

NADPH-diaphorase staining was strongly positive in all nasal polyp tissues studied, being localized mainly in airway epithelia (fig. 2a). Conversely, nasal mucosa tissues were faintly stained (fig. $2 b$ and 2c), but NADPHdiaphorase activity was also localized in epithelia, either in the airway (fig. 2b) or in the glandular epithelia (fig. 2c). 
No staining was found in control sections incubated without NADPH, and staining in the presence of $\rho$-nitrophenylphosphate was identical to that described above (data not shown), indicating that staining is due to NADPHdiaphorase activity and excluding a contribution from other enzymes.

\section{Discussion}

This study has shown the presence of NOS activity in inflamed and non-inflamed human upper airway tissues as detected either biochemically or histochemically. Our first approach consisted of measuring ${ }^{3} \mathrm{H}$-citrulline production from ${ }^{3} \mathrm{H}$-arginine in tissue homogenates as an index of NOS activity. The high variability of NOS activity found in nasal polyp tissues may be due to individual differences, but the fact that patients were receiving topical and/or oral steroid treatment almost certainly influenced these results. For ethical reasons, it was not admissible to discontinue the treatment before surgery.

Direct evidence for the presence of NOS activity in upper airways has, thus far, not been reported in humans, despite a previous description of NOS activity in the mouse olfactory and vomeronasal system [24], by means of histochemistry, immunohistochemistry and in situ hybridization. In humans, functional studies, reported by LUNDBERG and co-workers [18], have described the presence of NO in exhaled air of control subjects, apparently originating in the nasal airways. Our results fit well with these data and confirm by means of biochemical assay that NOS activity is present in human upper airways. More interestingly, our data establish a clear relationship between inflammation and the amount and isoform of NOS activity. Our results indicate that the upper airways constitutively express a NOS, both in inflamed and non-inflamed tissues, but that in inflamed tissues, such as nasal polyps, inducible NOS is upregulated. These data suggest not only that NO may play a physiological role in the upper airways, but also that NO is associated to inflammatory processes in the airways. In this respect, our results agree with those describing an increase in the amount of NO in exhaled air from mild asthmatics, that seems to originate in the lower airways [18].

Histochemical staining of NADPH-diaphorase (nitroblue tetrazolium formazan formation) confirms the biochemical data (citrulline production). NADPH-diaphorase is an enzyme which can be visualized by the reduction of tetrazolium salts to formazan in the presence of reduced NADPH. NADPH-diaphorase has been identified as an isoform of NOS [25]. Although NADPH-diaphorase is not an absolute marker for cells producing NO, the specificity of histochemical staining of NOS using NADPH-diaphorase reaction has been substantiated by some studies comparing histochemistry with immunostaining in intact tissues [26, 27]. Since the conversion of NADPH to NADP may be influenced by other enzymes, such as alkaline phosphatases or acid phosphatases, care must be taken to include appropriate controls and to avoid false positives [23]. For this reason, we have performed the staining either in the absence of $\beta$-NADPH or in the presence of $\rho$-nitrophenylphosphate, and the histochemical results presented here confirm the biochemical data.

Our results show that the staining is stronger in nasal polyp tissues (fig. 2a) than in nasal mucosa (fig. $2 b$ and c), but in both tissues the staining is localized to the epithelia, either to the airway epithelia (fig. $2 a$ and $b$ ) or to the glandular epithelia (fig. 2c). These data fully agree with the results of studies performed in human lung that localize NADPH-diaphorase throughout the airway epithelium [16] as well as in the NCI-H441 human bronchiolar epithelial cell line [28]. Thus, our findings suggest that the epithelium is a major source of NO production in human upper airways and stress the role of epithelial cells, not only as a structural cell, but also as a source of inflammatory mediators in chronically inflamed tissues, such as nasal polyps.

In summary, the present investigation shows that: 1) NOS activity is present in human upper airways; 2) it is localized in the epithelium; 3 ) constitutive NOS is expressed in both inflamed and noninflamed tissues; and 4) inducible NOS is only expressed in nasal polyp tissues. From these data, we conclude that NO may have an important physiopathological role in human upper airways.

Acknowledgements: The authors are indebted to all staff of the ENT Department of Hospital Valle de Hebrón for providing the tissues. The excellent technical assistance of N. Peña is greatly appreciated. They acknowledge the contribution of H. Cabodevila in liaising ENT consultants and researchers.

\section{References}

1. Nathan C. Nitric oxide as a secretory product of mammalian cells. FASEB J 1992; 6: 3051-3064.

2. Moncada S, Higss A. The L-arginine-nitric oxide pathway. N Engl J Med 1993; 329: 2002-2012.

3. Palmer RMJ, Ferrige AG, Moncada S. Nitric oxide accounts for the biological activity of endothelium-derived relaxing factor. Nature 1987; 327: 524-526.

4. Forstermann U, Schmidt H, Pollock J, et al. Isoforms of nitric oxide synthase, characterization and purification from different cell types. Biochem Pharmacol 1991; 42: 1849-1857.

5. Knowles RG, Moncada S. Nitric oxide synthase in mammals. Biochem J 1994; 298: 249-258.

6. Bredt D, Hwang P, Glatt C, Lowenstein C, Reed R, Snyder $\mathrm{S}$. Cloned and expressed nitric oxide synthase structurally resembles cytochrome P-450 reductase. Nature 1991; 351: 714-717.

7. Lamas S, Marsedn P, Li G, Tempst P, Michel T. Endothelial nitric oxide synthase: molecular cloning and characterization of a distinct constitutive enzyme isoform. Proc Natl Acad Sci 1992; 89: 6348-6352.

8. Lowenstein C, Glatt C, Bredt D, Snyder D. Cloned and expressed macrophage nitric oxide synthase contrast with the brain enzyme. Proc Natl Acad Sci 1991; 89: 6711-6715.

9. Jorens PG, Vermeire PA, Herman AG. L-arginine-dependent nitric oxide synthase: a new metabolic pathway in the lung and airways. Eur Respir J 1993; 6: 258-266.

10. Frostell C, Fratacci M, Wain J, Jones R, Zapol W. Inhaled 
nitric oxide: a selective pulmonary vasodilator reversing hypoxic pulmonary vasoconstriction. Circulation 1991; 83: 2038-2043.

11. Pepke-Zabe J, Higenbottam TW, Dinh-Xuan AT, Stone $\mathrm{D}$, Wallwork J. Inhaled nitric oxide as a cause of selective pulmonary vasodilatation in pulmonary hypertension. Lancet 1991; 338: 1173-1174.

12. Rossaint R, Falke KJ, López F, Slame K, Pison U, Zapol WM. Inhaled nitric oxide for the adult respiratory distress syndrome. N Engl J Med 1993; 328: 399-405.

13. Dupuy PM, Shore SA, Drazen JM, Frostell C, Hill WA, Zapol WM. Bronchodilator action of inhaled nitric oxide in guinea-pigs. J Clin Invest 1992; 90: 421-428.

14. Högman M, Frostell CG, Hedenström H, Hodestierne G. Inhalation of nitric oxide modulates adult human bronchial tone. Am Rev Respir Dis 1993; 148: 1474-1478.

15. Mayer B, Bohme E. $\mathrm{Ca}^{2+}$-dependent formation of an Larginine-derived activator of soluble guanylyl cyclase in bovine lung. FEBS Lett 1989; 256: 211-218.

16. Kobzik L, Brendt DS, Lowenstein CJ, et al. Nitric oxide synthase in human and rat lung: immunocytochemical and histochemical localization. Am J Respir Cell Mol Biol 1993; 9: 371-377.

17. Gustafsson LE, Leone AM, Persson MG, Wiklund NP, Moncada S. Endogenous nitric oxide is present in exhaled air of rabbits, guinea-pigs and humans. Biochem Biophys Res Commun 1991; 181: 852-857.

18. Alving K, Weitzberg E, Lundberg JM. Increased amount of nitric oxide in exhaled air of asthmatics. Eur Respir $J$ 1993; 6: 1368-1370.

19. Lundberg JON, Rinder J, Weitzberg E, Lundberg JM, Alving K. Nasally exhaled nitric oxide in humans originates mainly in the paranasal sinuses. Acta Physiol Scand 1994; 152: 431-432.
20. Ialeti A, Moncada S, Di Rosa M. Modulation of adjuvant arthritis by endogenous nitric oxide. BrJ Pharmacol 1993; 110: 701-706.

21. Middleton SJ, Shorthouse M, Hunter JO. Increased nitric oxide synthesis in ulcerative colitis. Lancet 1993; 341: 465-466.

22. Bredt DS, Snyder SH. Isolation of nitric oxide synthetase, a calmodulin requiring enzyme. Proc Natl Acad Sci 1990; 87: 682-685.

23. Leeflang-de Pijper A, Hulsmann W. Pitfalls in histochemical localization studies of NADPH generating enzymes or enzyme systems in rat small intestine. Histochemistry 1974; 39: 143-153.

24. Kishimoto J, Keveine EB, Hardwick J, Emson PC. Localization of nitric oxide synthase in the mouse olfactory and vomeronasal system: a histochemical, immunological and in situ hybridization study. Eur J Neurosci 1993; 5: 1684-1694.

25. Hope BT, Michael GJ, Knigge KM, Vincent SR. Neural NADPH diaphorase is an nitric oxide synthase. Proc Natl Acad Sci 1991; 88: 2811-2814.

26. Schmidt HG, Gagne G, Nakane M, Pollock J, Miller M, Murad F. Mapping of neural nitric oxide synthase in the rat suggest frequent co-localization with NADPH-diaphorase but not with soluble guanylyl cyclase, and novel paraneural functions for nitrinergic signal transduction. $J$ Histochem Cytochem 1992; 40: 1439-1456.

27. Dwason T, Bredt D, Fotuhi M, Hwang P, Snyder S. Nitric oxide synthase and neuronal NADPH diaphorase are identical in brain and peripheral tissues. Proc Natl Acad Sci 1991; 88: 7797-7801.

28. Shaul PW, North AJ, Wu LC, et al. Endothelial nitric oxide synthase is expressed in cultured human bronchial epithelium. J Clin Invest 1994; 94: 2231-2236. 